Reis, A., A. Braga, M. Lemes, R. Gribel and R. CollEVATTI (2009): Development and characterization of microsatellite markers for the Brazil nut tree Bertholletia excelsa Humb. \& Bonpl.(Lecythidaceae). Molecular Ecology Resources 9: 920-923.

RITLAND, K. (1989): Correlated matings in the partial selfer Mimulus guttatus. Evolution 43: 848-859.

RITLAND, K. (2002): Extensions of models for the estimation of mating systems using $\mathrm{n}$ independent loci. Heredity 88: 221-228.

SAMPSON, J. F. (1998): Multiple paternity in Eucalyptus rameliana (Myrtaceae). Heredity 81: 349-355.

SAnTos, C. F. and M. L. AIsy (2012): Interactions between carpenter bees and orchid bees (Hymenoptera: Apidae) in flowers of Bertholletia excelsa Bonpl. (Lecythidaceae). Acta Amazonica 42: 84-94.

Sebbenn, A. M. (2006): Sistema de reprodução em espécies arbóreas tropicais e suas implicações para a seleção de árvores matrizes para reflorestamentos ambientais. In: HigA, A. R. and L. D. Silva. Pomares de sementes de espécies florestais nativas. Curitiba: FUPEF, p. 93-138.

Silva, C. R. S., P. S. B. Albuquerque, F. R. ErveDosa, J. W. S. Mota, A. Figueira and A. M. SEBBENN (2011): Understanding the genetic diversity, spatial genetic structure and mating system at the hierarchical levels of fruits and individuals of a continuous Theobroma cacao population from the Brazilian Amazon. Heredity 106: 973-985.

SuJII, P. S., P. W. Inglis, A.Y. Ciampi, V. N. Solferini and V. C. R. AzEvedo (2013): Isolation and characterization of microsatellite markers for Bertholletia excelsa (Lecythidaceae) population genetic analysis. Genet. Mol. Res. 12: 5278-5282.

Sujit, P. S., K. Martins, L. H. O. Wadt, V. C. R. Azevedo and V. N. Solferini (2015): Genetic structure of Bertholletia excelsa populations from the Amazon at different spatial scales. Conserv. Genet. DOI 10.1007/s10592-015-0714-4.

Surles, S. E., J. Arnold, A. Schabel, J. L. HAMrick and B. C. BongARTEN (1990): Genetic relatedness in open pollinated families of two leguminous tree species, Robinia pseudoacacia L. and Gleditsia triacanthos L. Theor. Appl. Genet. 80: 49-56.

Tambarussi, E. V., D. Boshier, R. Vencovsky, M. L. M. Freitas and A. M. Sebbenn (2015): Paternity analysis reveals significant isolation and near neighbour pollen dispersal in small Cariniana legalis Mart. Kuntze populations in the Brazilian Atlantic Forest. Ecology and Evolution. doi: 10.1002/ece3.1816

WAdt, L. H. O., K. A. Kainer and D. A. P. GomesSILvA (2005): Population structure and nut yield of a Bertholletia excelsa stand in Southwestern Amazonia. Forest Ecology and Management 211: 371384.

Wadt, L. H. O., K. A. Kainer, C. Staudhammer and R. SERRENo (2008): Sustainable forest use in Brazilian extractive reserves: Natural regeneration of Brazil nut in exploited populations. Biological Conservation 141: 332-346.

WARD, M., C. W. Dick, R. Gribel and A. J. Lowe (2005): To self, or not to self... A review of outcrossing and pollen-mediated gene flow in Neotropical trees. Heredity 95: 246-254.

\title{
PCR-based detection of single sequence variants from a natural collection of the non-model tree species European Aspen Populus tremula (L.)
}

\author{
By S. WinkleR ${ }^{1)}$, K. Linke ${ }^{2)}$, N. GscheideL ${ }^{1)}$, M. MeYeR ${ }^{2)}$ and D. KrabeL ${ }^{2), *)}$
}

(Received $11^{\text {th }}$ November 2015)

\begin{abstract}
In the present study we present and discuss the identification of species-specific SNPs to

1) MPI of Molecular Cell Biology and Genetics, DNA Sequencing Facility, Pfotenhauerstr. 108, D-01307 Dresden, Germany.

$\left.{ }^{2}\right)$ Molecular Physiology of Woody Plants Group, Dresden University of Technology, Pienner Str. 7, D-01737 Tharandt, Germany.

*) Corresponding author: DoRIS KRABEL.

E-Mail: krabel@forst.tu-dresden.de
\end{abstract}

rule out any experimental influence of speciesspecific primer design (Populus tremula vs. the closely related model-species Populus trichocarpa) on the detectability of SNPs. Applying a species-optimized method, partial sequences of 14 genes involved in xylem cell development, xylogenesis, pectin formation, and drought stress reaction were analyzed at the genomic level. About $3 \mathrm{Mb}$ of sequence information were generated by Sanger sequencing technology and 258 sequence variants were 
identified. 15 out of these represent insertions/deletions located exclusively in noncoding regions and the remaining 243 are SNPs found in coding and non-coding regions of candidate genes.

The introduction of a species-specific SNP detection pipeline will help to detect nucleotide variants in $P$. tremula and to conduct association mapping in natural $P$. tremula populations.

Key words: drought stress tolerance, natural population, Populus tremula, SNP, xylem cell formation

\section{Introduction}

Within the last decade the genus Populus has become one of the main research objects of molecular genetics on woody plants. Poplar species are easily to propagate compared to other tree or shrub species, which facilitates the cultivation of plants. In addition, the genome is relatively small $(2 \mathrm{n}=38$, ca. $550 \mathrm{Mbp})$. Both are favorable characteristics for a plant species to become a model organism (STRAUSS and MARTIN, 2004).

European Aspen (Populus tremula, L.) is a deciduous tree species widely distributed in the Northern hemisphere (ECKENWALDER, 1996). Its geographic distribution ranges from cool and temperate regions in Northern Europe and North Eastern Asia to warm and dry sites in Southern Europe and North Africa (ECKENWALDER, 1996). P. tremula belongs to the family of Salicacea and is closely related to poplar species that are mostly used for short rotation forestry. Though, due to its comparably lower biomass production $P$. tremula does not count amongst the typical plantation tree species in Europe. Nevertheless like other widely distributed tree species, adaptive genetic variation, which might reflect the capability of a subpopulation to adapt to different environmental conditions (especially to drought) in combination with an acceptable biomass production has to be expected for European aspen which makes this tree species an interesting object of investigations.

One promising method for identification of drought-adapted genotypes is an association mapping approach based on the characterization of SNPs (single nucleotide polymorphisms) being located in candidate genes. SNP-loci have been identified for a number of plant species including forest trees (e.g. Populus tremula:
INGVARSSON, 2005; SeEB et al., 2011; SEIFERT et al., 2012). Although most SNPs do behave selectively neutral and can be used in population genetic analysis in addition to or instead of other neutral markers (SEIFERT et al., 2012), a comparably small number of SNPs are likely to be under selection and can be associated with phenotypic traits (YoshiURA et al., 2006; SEIFERT et al., 2012).

In the present study, we introduce a reliable and robust method for the detection of single nucleotide polymorphisms within candidate genes related to traits that are mainly involved in drought stress tolerance in Populus tremula. In contrast to Ingvarsson (2008), who investigated a total of 77 amplicons distributed randomly over the genome of European aspen, we focused on selected candidate genes. For individuals selected from different populations and environments this approach seemed to be a promising method to detect SNP variation fast and efficiently (CARDON and BELL, 2001; INGVARSSON, 2005) as a basis for a future association mapping study and marker-assisted selection.

\section{Materials and methods}

\section{Sample collection}

To cover a wide spectrum of environmental conditions such as water availability and soil conditions, 108 P. tremula genotypes were collected from eleven natural sites in Germany (9 to 11 trees per subpopulation). Among these eleven sites, ten sites were selected along a North to South gradient beside and $50 \mathrm{~km}$ far from the river Oder. Additionally one subpopulation was sampled in the rocky area of the Black Forest region (Figure 1). Only trees separated by a distance of 1-2 $\mathrm{km}$ were collected to ensure the sampling of genetically distinct trees.

\section{DNA extraction}

Total genomic DNA was extracted from frozen or dried leaves according to DoYle and Doyle 1987. Several DNA extractions from cambium were done using the DNeasy plant mini-prep kit (QIAGEN, Hilden, Germany). The amount and the quality of the genomic DNA were analyzed in $0.8 \%$ agarose gels. For subsequent PCR applications genomic DNA was diluted 1 in 100 in water. 


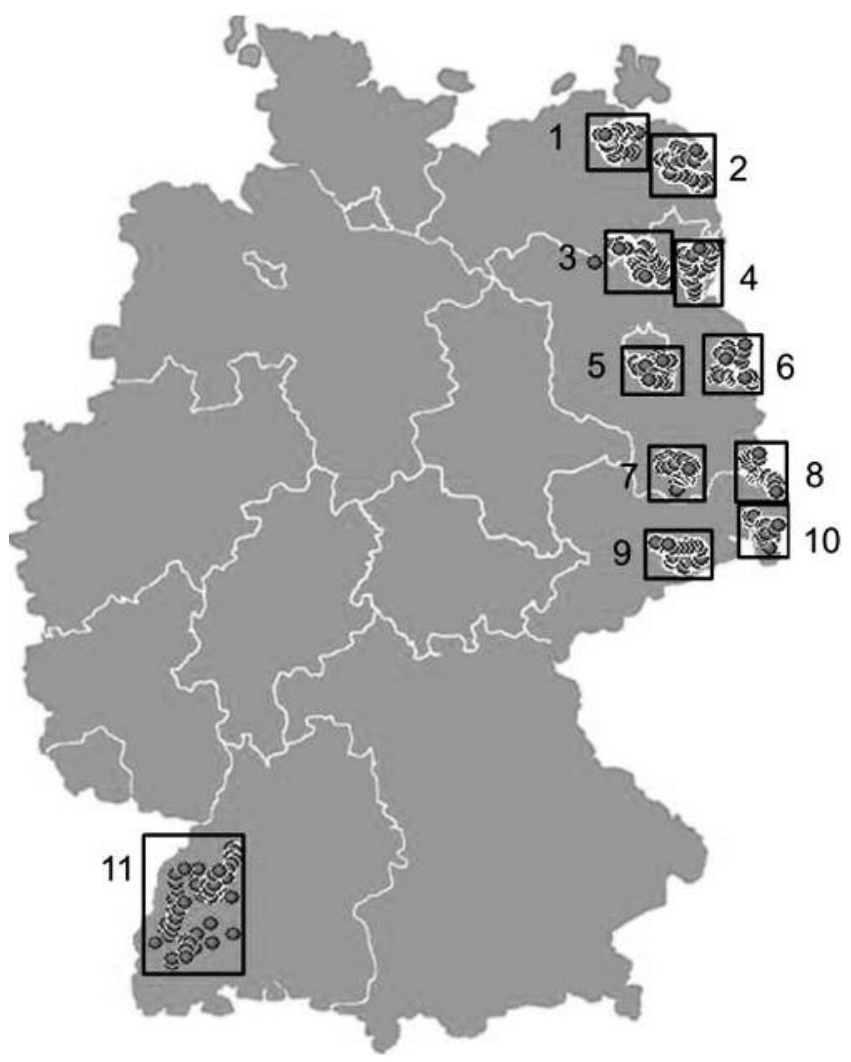

Figure 1. - Collection sites of individual trees of the P. tremula natural collection in Germany. GPS data: Greifswald: $54^{\circ} 6^{\prime} \mathrm{N}, \quad 13^{\circ} 23^{\prime} \mathrm{E}$; Usedom: $53^{\circ} 52^{\prime} \mathrm{N}$, $13^{\circ} 55^{\prime} \mathrm{E}$; Templin: $53^{\circ} 7^{\prime} \mathrm{N}, 13^{\circ} 30^{\prime} \mathrm{E}$; Schwedt: $53^{\circ} 4^{\prime} \mathrm{N}$, $14^{\circ} 17^{\prime} \mathrm{E}$; Berlin: $52^{\circ} 31^{\prime} \mathrm{N}, 13^{\circ} 24^{\prime} \mathrm{E}$; Frankfurt/Oder: $52^{\circ} 21^{\prime} \mathrm{N}, 1^{\circ} 33^{\prime} \mathrm{E}$; Finsterwalde: $51^{\circ} 38^{\prime} \mathrm{N}, 13^{\circ} 43^{\prime} \mathrm{E}$; Bad Muskau: $51^{\circ} 33^{\prime} \mathrm{N}, 1^{\circ} 43^{\prime} \mathrm{E}$; Dippoldiswalde: $50^{\circ} 54^{\prime} \mathrm{N}, \quad 13^{\circ} 40^{\prime} \mathrm{E}$; Zittau: $50^{\circ} 51^{\prime} \mathrm{N}, \quad 14^{\circ} 48^{\prime} \mathrm{E}$ and Schwarzwald: $48^{\circ} 28^{\prime} \mathrm{N}, 8^{\circ} 10^{\prime} \mathrm{E}$.

\section{Candidate gene selection}

Candidate genes were selected for their physiological function in the context of drought adaptive behavior. Table 1 summarizes the genes, which were chosen as candidates. First we focused on genes that are reported to be directly up-regulated upon water deficiency. These were Drought-sensitive 1 (drs1), stable protein ( $\mathrm{Sp1}$ ) and Metallothionein 2A (Mt2a). SLAC1 and erecta homologues are involved in regulation and movement of stomata in leaves as a response to humidity changes, whereas the aquaporin PIP2.5-gene is directly involved in water transport. Alpha-expansin $(\alpha-\exp )$ regulates cell-wall extension and stress relaxation. Secondly, other candidate genes were chosen due to their function in xylogenesis, xylem cell development and pectin formation, among these are the $\mathrm{K}^{+}$channel protein $k p t 1$, the high-affinity potassium uptake transporter kup1, the potassium channel $p t k 2$, an outward rectifying potassium channel ptork, a MADS box protein ptm5, UDP-glucose dehydrogenase (UGDH), and UDP-glucose pyrophosphorylase (UGP). In the course of this study, we identified $P$. tremula homologues of Drs1, erecta, $m t 2 a$, and SLAC1 (Accession numbers: drs1, KC768063; erecta, KC768064; $m t 2 a, \quad \mathrm{KC768065;}$ SLAC1, $\mathrm{KC768066).}$

\section{P. tremula-specific PCR design}

Since $P$. tremula-specific whole genome information is not published yet, protein sequences of candidate genes as summarized in Table 1 were obtained from Genbank and Refseq, respectively. Protein sequences were blasted against the $P$. trichocarpa genome (TUSKAN et al., 2006), making use of the tools of the Phytozome project (GoODSTEIN et al., 2012: JGI v2.2, Populus genome assembly: http://www.phytozome.net/poplar.php). Identified candidate loci (blast hits) were manually examined for a) any duplicated sequence, b) for potential paralogs within the $P$. trichocarpa genome, and c) for the correct annotation of the candidate gene. If more than one candidate locus was identified for one gene, protein and nucleotide sequence comparisons were performed for these hits using CLUSTALW and the closest homologue was chosen for amplicon design.

P. trichocarpa-specific PCR primers were designed using the primer3-tool (ROZEN and SKALETSKY, 2000) applying these criteria: (1) PCR fragments are designed that allow sequencing over internally located primer binding sites that subsequently represent a reference for $P$. tremula-specific primer pairs, (2) primers which are located adjacent to exons to screen as much coding region as possible, (3) if gene annotation allows, primer pairs are designed which are located in coding sequences but not in functional domains to avoid unspecific binding based on high sequence conservation between functional domains. An overview of all primers (trichocarpa-specific, tremula-specific and tremula specific sequencing primers) is summarized in Table 2.

PCR and sequencing of PCR fragments has been performed as described in WINKLER et al. (2011). P. trichocarpa-derived primer pairs were tested on genomic DNA of one $P$. trichocarpa and eleven $P$. tremula trees. PCRs were done in a total volume of $10 \mu \mathrm{l}$ containing $2 \mu \mathrm{M}$ primer, $2 \mathrm{mM} \mathrm{MgCl}_{2}, 0,2 \mu \mathrm{M}$ dNTP each, $25 \mathrm{mM}$ 
Table 1. - List of candidate genes.

\begin{tabular}{|c|c|c|c|c|c|}
\hline Gene & $\begin{array}{l}\text { Accession } \\
\text { Number } P \text {. } \\
\text { tremula }\end{array}$ & $\begin{array}{l}\text { Genomic position } \\
(\text { P. trichocarpa v2.2) }\end{array}$ & Screened exon & Physiological function & Reference \\
\hline \multirow{2}{*}{ Drsl } & \multirow{2}{*}{ KC768063 } & \multirow{2}{*}{ LG 18: 12,658,160 - 12,659,729 } & exon 3 & \multirow{2}{*}{ Response to water deprivation, ubiquitin ligase complex } & \multirow{2}{*}{ Lee et al., 2008} \\
\hline & & & exon 4 & & \\
\hline \multirow{2}{*}{ Erecta } & \multirow{2}{*}{ KC768064 } & \multirow{2}{*}{ LG $6: 22,390,775-22,393,386$} & exon $23-24$ & \multirow{2}{*}{$\begin{array}{l}\text { Transpiration, transmembrane receptor protein kinase } \\
\text { activity }\end{array}$} & \multirow{2}{*}{$\begin{array}{l}\text { Masle et al., 2005; Hamanishi et al., } \\
\qquad 2012\end{array}$} \\
\hline & & & exon $25-26$ & & \\
\hline$a-\exp$ & AY435099 & $\begin{array}{l}\text { LG } 1: 24,014,878-24,017,296 \\
\text { LG } 9: 4,301,229-4,303,484\end{array}$ & not done ${ }^{1}$ & Cell-wall extension and stress relaxation & Gray-Mitsumune et al., 2004 \\
\hline KptI & AJ344623 & LG 4: 14,291.677-14.292,374 & exon $7-10$ & $\begin{array}{l}\text { Inward potassium channel, potassium dependent } \\
\text { xylogenesis }\end{array}$ & Langer et al., 2002 \\
\hline \multirow{2}{*}{ Kupl } & \multirow{2}{*}{ AJ299422 } & LG $3: 13,771,063-13,771,674$ & exon $2-3$ & \multirow{2}{*}{$\begin{array}{l}\text { Potassium transporter/uptake, potassium dependent } \\
\text { xylogenesis }\end{array}$} & \multirow{2}{*}{ Langer et al., 2002} \\
\hline & & LG $3: 13,767,144-13,767,874$ & exon 9 & & \\
\hline Mt $2 a$ & KC768065 & LG 6: $6,215,377-6,215,954$ & exon 2 & Metallothionein, abiotic stress response & $\begin{array}{l}\text { Street et al., 2006; Wilkins et al., } \\
\text { 2009, Yeh et al., } 1995\end{array}$ \\
\hline PIP2.5 & AJ849328 & $\begin{array}{l}\text { LG 16: } 6,990,700-6,991,987 \\
\text { LG } 9: 2,408,396-2,409,868\end{array}$ & not done $e^{2}$ & Aquaporin, water conduction & Marjanovic et al., 2005 \\
\hline \multirow{2}{*}{ Ptk2 } & \multirow{2}{*}{ AJ271447 } & LG $3: 1,122,870-1,123,791$ & not done $(7-8)^{3}$ & \multirow{2}{*}{$\begin{array}{l}\text { Voltage gated potassium channel, potassium dependent } \\
\text { xylogenesis }\end{array}$} & \multirow{2}{*}{$\begin{array}{l}\text { Langer et al., 2002; } A \text { rend et al., } \\
\qquad 2005\end{array}$} \\
\hline & & LG 3: $1,122,122-1,122,548$ & exon 9-10 & & \\
\hline \multirow{2}{*}{ Ptm5 } & \multirow{2}{*}{ AF 377868} & LG 14:5,289,861 - 5,290,477 & exon 1 & \multirow{2}{*}{$\begin{array}{l}\text { MADS-box protein, transcription lactor activity, wood } \\
\text { vascular development }\end{array}$} & \multirow{2}{*}{ Cseke et al., 2003} \\
\hline & & LG 14: 5,283,399 - 5,284,908 & exon 3-4 & & \\
\hline \multirow{2}{*}{ Ptork } & \multirow{2}{*}{ AJ271446 } & LG $12: 3,217,585-3,218,200$ & exon 3-4 & \multirow{2}{*}{$\begin{array}{l}\text { Outward rectifying potassium channel, potassium } \\
\text { dependent xylogenesis }\end{array}$} & \multirow{2}{*}{ Langer et al., 2002} \\
\hline & & LG 12: 3,214,335-3,214,910 & exon 8-9 & & \\
\hline$S L A C l$ & KC768066 & LG $15: 6,085,516-6,085,885$ & exon $2-3$ & $\begin{array}{c}\text { C4-dicarboxylate transporter/malic acid transport } \\
\text { protein, regulation of stomatal movements (humidity } \\
\text { response) }\end{array}$ & Vahisalu et al., 2008 \\
\hline Spl-1 & AJ276517 & LG 10: $15,141,391-15,142,213$ & exon $1-2$ & \multirow{2}{*}{$\begin{array}{l}\text { Heat stable protein, response to stress stimuli } \\
\text { (temperature, salt), water transport }\end{array}$} & \multirow{2}{*}{ Wang et al., 2002} \\
\hline$S p l-2$ & AJ 276517 & LG 10: $14,928,636-14,929,429$ & not done $\mathrm{e}^{4}$ & & \\
\hline$U D G H$ & AF053973 & $\begin{array}{l}\text { LG 4: } 10,620,227-10,621,029^{5} \\
\text { LG 17: } 12,927,539-12,928,338\end{array}$ & exon 1 & $\begin{array}{l}\text { UDP-glucose 6-dehydrogenase activity, formation of } \\
\text { pectin }\end{array}$ & Johansson et al., 2002 \\
\hline UGP & AY260746 & $\begin{array}{l}\text { LG4: } 6,008,392-6,013,141 \\
\text { LG17: } 967,805-972,392\end{array}$ & not done & UDP-glucose pyrophosphorylase, formation of pectin & Johansson et al., 2002 \\
\hline
\end{tabular}

${ }^{1}$ Duplicated region.

${ }^{2}$ Gene family of aquaporins that consists of more than two very similar versions.

${ }^{3}$ PCR failed.

${ }^{4}$ Partially duplicated sp1 locus.

${ }^{5}$ Specific primers for UDGH homolog are located on LG4.

tricine, $85 \mathrm{mM}$ ammoniumacetate, $7 \%$ glycerol, 1,6\% DMSO, 0,5 U Taq-polymerase, 5-50 ng genomic DNA. Cycling conditions for the PCRs were as follows: $94^{\circ} \mathrm{C}$ for $2 \mathrm{~min}, 30$ cycles of $94^{\circ} \mathrm{C}$ for $30 \mathrm{sec}, 57^{\circ} \mathrm{C}$ (or primer optimized annealing temperature) for $20 \mathrm{sec}, 72^{\circ} \mathrm{C}$ for $1 \mathrm{~min}$, and a final extension at $72^{\circ} \mathrm{C}$ for $10 \mathrm{~min}$. The resulting PCR fragments were visualized and quantified on $1 \%$ agarose gels, diluted to a final concentration of $10-20 \mathrm{ng} / \mathrm{\mu l}$ and directly used for DNA Sequencing (Sanger big dye terminator technology). Sanger sequencing was performed according to the manufacturers' protocol making use of low input conditions. The sequencing reaction contains $2-5 \mathrm{ng}$ template DNA, $0.2 \mu l$ big dye terminator, $0,4 \mu \mathrm{l} 5 \mathrm{x}$ sequencing buffer, and $2 \mu \mathrm{M}$ sequencing primer in a total volume of $8 \mu \mathrm{l}$. Cycling was performed as follows: $96^{\circ} \mathrm{C}$ for $1 \mathrm{~min}, 30$ cycles of $96^{\circ} \mathrm{C}$ for $10 \mathrm{sec}, 52^{\circ} \mathrm{C}$ for $5 \mathrm{sec}, 60^{\circ} \mathrm{C}$ for $3 \mathrm{~min}$. Sanger sequencing was performed on an AB3730XL DNA sequencer.

If PCR results were either unspecific or failed in P. tremula samples, PCR conditions were optimized for the annealing temperature. If heterozygous indels were found that were not resolved by any of the sequencing primers, internal $P$. tremula-specific sequencing primers were designed to cover as much information as possible.

DNA sequences of all tested individuals were compared and analyzed for differences between both species (cross-species variances) as well as 
Table 2. - P. tremula and P. trichocarpa-specific primer sequences and location of the primer in annotated locus.

\begin{tabular}{|c|c|c|c|c|c|c|}
\hline gene, exon & primer pairs $P$. trichocarpa & location & primer pairs $P$, tremula & location & Internal sequencing primer $P$. tremula & location \\
\hline Drs1, 3 & $\begin{array}{l}\text { 5'AGAGAAGAGGGAATTTGAGGG } \\
\text { 5'AGGATTAAACGAGCACTTGTC }\end{array}$ & $\begin{array}{l}\text { exon } \\
\text { intron }\end{array}$ & \begin{tabular}{|l|} 
5' TGTTCGCGTTTCTGTGGAGT \\
5'AGAACACTGCGGTATGATAAAG
\end{tabular} & $\begin{array}{l}\text { intron } \\
\text { intron }\end{array}$ & & \\
\hline Drs1, 4 & $\begin{array}{l}\text { 5' GGCCACTAGTTCCTCAGATGC } \\
\text { 5'ATCATGTCCAGGAAGATTGG }\end{array}$ & $\begin{array}{l}\text { exon } \\
\text { intron }\end{array}$ & $\begin{array}{l}\text { 5' GCCCACTTTAATTTGGAGAG } \\
\text { 5' TGATGCCCTTCAATGGAACC } \\
\end{array}$ & $\begin{array}{l}\text { intron } \\
\text { intron } \\
\end{array}$ & & \\
\hline Erecta, $23+24$ & $\begin{array}{l}\text { 5' CAGAGCGAGGTATTCAGATG } \\
\text { 5' CTCGATACTGCTCTGCTTTG }\end{array}$ & $\begin{array}{c}\text { exon } \\
\text { 3'UTR }\end{array}$ & \begin{tabular}{|l|} 
5' CGGTAATACCTTTTCTGCAG \\
5' CGAGGACTACAATCATGGTG
\end{tabular} & $\begin{array}{l}\text { intron } \\
\text { exon }\end{array}$ & $\begin{array}{l}\text { 5' GTAGGTGCATGCAAG GAGAG } \\
\text { 5' TAATTTTCAACTCCAAGACTATC }\end{array}$ & $\begin{array}{l}\text { intron } \\
\text { intron }\end{array}$ \\
\hline Erecta, $25+26$ & $\begin{array}{l}\text { 5' CAAGGATATTCCCTGTCACC } \\
\text { 5' GCTTCTCGTGGTCCTACAG }\end{array}$ & $\begin{array}{c}\text { exon } \\
\text { 3'UTR }\end{array}$ & $\begin{array}{l}\text { 5' TCTCCTTGCATGCACCTAC } \\
\text { 5, CTCGATACTGCTCTGCTTTG }\end{array}$ & $\begin{array}{l}\text { intron } \\
\text { intron }\end{array}$ & $\begin{array}{l}\text { 5' CATTGTCAACTGCTTTCCTT } \\
\text { 5' TCTGACACGGATAAGAAACC } \\
\text { 5' GGTTTCTTATCCGTGTCAGA }\end{array}$ & $\begin{array}{l}\text { exon } \\
\text { intron } \\
\text { intron }\end{array}$ \\
\hline Kpt1, 7-10 & $\begin{array}{l}\text { 5'ATCAATGTTTGCCCAGTTTC } \\
\text { 5' GTTTCGCTATCCTCAACTGC }\end{array}$ & $\begin{array}{l}\text { intron } \\
\text { intron }\end{array}$ & $\begin{array}{l}\text { 5' GCAGAACGAAGCTCCTACAG } \\
\text { 5' CTTTCTTGTAGCCTTTGATCC }\end{array}$ & $\begin{array}{l}\text { exon } \\
\text { exon }\end{array}$ & & \\
\hline Kup1, 2+3 & $\begin{array}{l}\text { 5' TCCAATAAATCATGGTACGC } \\
\text { 5' GGTAATAAACACAGCAGCAC }\end{array}$ & $\begin{array}{l}\text { 5'UTR } \\
\text { exon }\end{array}$ & \begin{tabular}{|l|} 
5' TGTCTTGATCGTTGCTCTTG \\
5, CAAACTTCTTGAACCGAGATG
\end{tabular} & $\begin{array}{l}\text { intron } \\
\text { exon }\end{array}$ & & \\
\hline Kup1, 9 & $\begin{array}{l}\text { 5' GAAAGCTGTTCTTACCTTTGC } \\
\text { 5' CTGCTCTCCTTATTGCCATC }\end{array}$ & $\begin{array}{l}\text { intron } \\
\text { exon }\end{array}$ & $\begin{array}{l}\text { 5' AAAGCTGATGTTGCTACTACC } \\
\text { 5' TCAGATGACCTCACAACTGC }\end{array}$ & $\begin{array}{l}\text { intron } \\
\text { exon }\end{array}$ & & \\
\hline$M t 2 a, 1+2^{1}$ & $\begin{array}{l}\text { 5' CACTTCGCGCAGTTTCC } \\
\text { 5'AGAGCTGCAAATCCAAGAAG }\end{array}$ & $\begin{array}{l}\text { 5'UTR } \\
\text { 3'UTR } \\
\end{array}$ & \begin{tabular}{|l|} 
5' TTGCAGGGATAAGCATGACG \\
5' ACAAGAGACAAGAGACAACC
\end{tabular} & $\begin{array}{l}\text { intron } \\
3^{\prime} \mathrm{UTR}^{2} \\
\end{array}$ & & \\
\hline Ptk2, 7+8 & $\begin{array}{l}\text { 5' TGTGATCTTATGTGCCTAACG } \\
\text { 5' AATTCCCATGCATGTTCTG }\end{array}$ & $\begin{array}{l}\text { intron } \\
\text { intron }\end{array}$ & not done & & & \\
\hline Ptk2, 9+10 & $\begin{array}{l}\text { 5' GATTCCCACCTACTGATTCG } \\
\text { 5' CATGAGGTGCATTCTTGTTC }\end{array}$ & $\begin{array}{l}\text { intron } \\
\text { exon }\end{array}$ & $\begin{array}{l}\text { 5' AGGACATGAAGAGTGTGTGG } \\
\text { 5' GCACCGCTCATTACTAGC }\end{array}$ & $\begin{array}{l}\text { exon } \\
\text { exon }\end{array}$ & & \\
\hline Ptm5, 1 & $\begin{array}{l}\text { 5'AAGCTCTCGTGGGTTTATTG } \\
\text { 5'ATTATTGGAACGGGCAAAG }\end{array}$ & $\begin{array}{l}\text { 5'UTR } \\
\text { intron }\end{array}$ & $\begin{array}{l}\text { 5' TCCCTCCACTTTCTTACCTG } \\
\text { 5' GAGAGAGAGAGAGGCACACAC }\end{array}$ & $\begin{array}{l}\text { intron } \\
\text { intron }\end{array}$ & 5'ATCAAAGGAGCCAGACACG & intron \\
\hline Ptm5, 3+4 & $\begin{array}{l}\text { 5' TGTTGTAGATGCTTGCGAAC } \\
\text { 5' ACATGCAACTGTTGACGAC }\end{array}$ & $\begin{array}{l}\text { intron } \\
\text { intron }\end{array}$ & \begin{tabular}{|l|} 
5' ATAGGATAAGGGTGGAAGG \\
5' TTCTCTACAGCCTTTGGTTTC
\end{tabular} & $\begin{array}{l}\text { exon } \\
\text { intron }\end{array}$ & & \\
\hline Ptork, 3+4 & $\begin{array}{l}\text { 5' CATTGCCATTAGGTCTGTACC } \\
\text { 5' CGTGGATTTGTCTAGCAATG }\end{array}$ & $\begin{array}{l}\text { exon } \\
\text { intron }\end{array}$ & $\begin{array}{l}\text { 5' GAAATCTCGGTTCTTGGTTG } \\
\text { 5' TGCCACTCATCTGGACTTC }\end{array}$ & $\begin{array}{l}\text { exon } \\
\text { intron }\end{array}$ & & \\
\hline Ptork, 8+9 & $\begin{array}{l}\text { 5' CCTGTCTCTGAGTGTGTTGG } \\
\text { 5' TAATGCAACGGTTCAAGTTC }\end{array}$ & $\begin{array}{l}\text { intron } \\
\text { intron }\end{array}$ & $\begin{array}{l}\text { 5' GCAAACCTATAGCTCATTTGG } \\
\text { 5' AGCCTTGTTAGGATCTGCTC }\end{array}$ & $\begin{array}{l}\text { exon } \\
\text { exon }\end{array}$ & & \\
\hline$S L A C, 2+3$ & $\begin{array}{l}\text { 5' ATGTCAGGAGGACAGAGAAGG } \\
\text { 5' GAGGTCCTGGAGTACGAAT }\end{array}$ & $\begin{array}{l}\text { exon } \\
\text { exon }\end{array}$ & $\begin{array}{l}\text { 5' TATATTTCTGTCATGGACATTC } \\
\text { 5' GTACGAATGCGTGCACT }\end{array}$ & $\begin{array}{l}\text { intron } \\
\text { exon }\end{array}$ & & \\
\hline Sp $1,1+2$ & $\begin{array}{l}\text { 5' GGACATTAGGCGTGGAAAG } \\
\text { 5' TATCGATGCTGGTTCTTTCC }\end{array}$ & $\begin{array}{l}\text { 5'UTR } \\
\text { 3'UTR } \\
\end{array}$ & $\begin{array}{l}\text { 5' GGCAGAGCATCATGCAG } \\
\text { 5' AGCTCATTCGAGGATAATGG }\end{array}$ & $\begin{array}{l}\text { 5'UTR } \\
\text { 3'UTR } \\
\end{array}$ & & \\
\hline Sp1, short & $\begin{array}{l}\text { 5' GGCGGGTCTACCACCAC } \\
\text { 5' CACAAACAAGATCAAGACACG }\end{array}$ & $\begin{array}{l}\text { intron } \\
\text { intron }\end{array}$ & not done & & & \\
\hline$U D G H, 1$ & $\begin{array}{l}\text { 5' ATCTACAACGGCAGGTTAGC } \\
\text { 5' CCAACACTAGCATTCAAGAAC }\end{array}$ & $\begin{array}{l}\text { intron } \\
\text { exon }\end{array}$ & $\begin{array}{l}\text { 5' TGAATTTCCCTTCTTTCAGG } \\
\text { 5' TCCTTTCCAACAGCATAGGC }\end{array}$ & $\begin{array}{l}\text { intron } \\
\text { exon }\end{array}$ & & \\
\hline
\end{tabular}

${ }^{1}$ A nested PCR approach was used to amplify exon 2 of Mt2a: inner primers were used to amplify from the PCR fragment generated by the outer primer set.

${ }^{2}$ Untranslated regions: considered are $500 \mathrm{bp}$ upstream or downstream of coding sequence since annotation was mostly missing. Bold: Nucleotides that differ in the primer binding sites of $P$. tremula and $P$. trichocarpa, shown is $P$. tremula sequence.

between $P$. tremula individuals (within-species variances). $P$. trichocarpa-derived primers served as templates for the design of $P$. tremulaspecific primer pairs. These primer pairs were tested again for specificity and performance on the $P$. tremula trees. An overview of all designed primer pairs including sequencing primers is presented in Table 2.

\section{Detection of sequence variation and statistical analysis of SNPs in the P. tremula natural populations}

PCR fragments were amplified and sequenced from the $P$. tremula collection making use of P. tremula-specific PCR and sequencing primers. SNPs in these regions were detected automatically by the Polyphred software package that uses Phred-based base calling and quality assignments with subsequent detection of heterozygous peaks in sequence assemblies performed by Phred, conditions are as follows: the peak drop ratio is 0.55 , a second peak ratio of 0.15 and an average sequence quality of 30 (NiCKerson et al., 1997; BHANGALE et al., 2006). Small and resolvable indels of 1 to $100 \mathrm{bp}$ in size were detected on sequence alignments (CLUSTALW) making use of the MacVector sequence analysis tool (MacVector, Inc., North Carolina, US). Sequence variation was documented for each individual of the $P$. tremula collection. For each SNP in the total population the genetic diversity was estimated by calculating the observed and expected heterozygosities and p-values. All calculations were performed with PowerMarker version 3.25. Tests for Hardy-Weinberg equilibrium (HWE) were performed for each SNP using the exact test implemented in PowerMarker version 3.25 (LIU and Muse, 2005). Application of Bonferroni correction was done in a conservative manner (corrected $\alpha$-level: 0.05/243 $=0.0002$ ). 
Determination of an allele bias caused

by cross-species primer and PCR conditions

The effect of cross-species PCR and sequencing conditions ( $P$. trichocarpa-derived primers on $P$. tremula individuals) on SNP detection was compared to within-species conditions (P. tremula-derived primers on $P$. tremula individuals). For this experiment, four sets of $P$. trichocarpa(representing cross-species and tremula-specific primer pairs representing three different genes (drs1 exon 3, drs1 exon 4, erecta exon 23+24, $m t 2 a$ exon 2) were amplified and sequenced from the $P$. tremula collection. Three independent rounds of PCR were performed with $P$. tremula-specific primers and two independent rounds with $P$. trichocarpa-specific primers. Differences within one data set (PCR- and sequence-derived errors, inner-species dataset) and between $P$. trichocarpa- and $P$. tremulaspecific data were determined. The observed and expected heterozygosity values were calculated for each locus (data not shown). The inbreeding coefficient $\left(\mathrm{F}_{\mathrm{IS}}\right)$ and the number of loci that deviate significantly from HWE expectations after conservative Bonferroni correction (corrected $\alpha$-level: $0.05 / 81=0.0006$ ) are given for each amplicon. All calculations were done with the software PowerMarker version 3.25 (Table 3)

Table 3. - Heterozygosity of the wild population, inbreeding coefficient and deviation from HWE for the tested amplicons.

\begin{tabular}{|c|c|c|c|c|c|c|}
\hline \multirow{2}{*}{ Gene } & \multirow{2}{*}{ exon } & \multirow{2}{*}{$\begin{array}{c}\text { Total No. } \\
\text { of SNPs }\end{array}$} & \multicolumn{2}{|l|}{ Heterozygosity } & \multirow{2}{*}{ F $_{\text {IS }}$} & \multirow{2}{*}{$\begin{array}{l}\text { Out of } \\
\text { HWE }^{1}\end{array}$} \\
\cline { 5 - 6 } & & & exp & Obs & & \\
\hline \multirow{2}{*}{ Drs1 } & 3 & 14 & 0,204 & 0,180 & 0,125 & 0 \\
& 4 & 19 & 0,203 & 0,134 & 0,443 & 4 \\
\hline \multirow{2}{*}{ Erecta } & $23+24$ & 29 & 0,246 & 0,183 & 0,232 & 1 \\
& $25+26$ & 19 & 0,224 & 0,221 & 0,006 & 0 \\
\hline Kpt1 & $7-10$ & 17 & 0,275 & 0,260 & 0,024 & 0 \\
\hline \multirow{2}{*}{ Kup1 } & $2+3$ & 4 & 0,097 & 0,092 & 0,025 & 0 \\
\hline Mt2a & 2 & 5 & 0,332 & 0,321 & 0,012 & 0 \\
\hline Ptk2 & $9+10$ & 16 & 0,284 & 0,237 & 0,159 & 3 \\
\hline \multirow{2}{*}{ Ptm5 } & 1 & 18 & 0,143 & 0,111 & 0,132 & 0 \\
& $3+4$ & 17 & 0,182 & 0,156 & 0,189 & 0 \\
\hline \multirow{2}{*}{ Ptork } & $3+4$ & 12 & 0,318 & 0,245 & 0,282 & 3 \\
\hline SLAC1 & $2+9$ & 10 & 0,117 & 0,113 & 0,015 & 0 \\
\hline Sp1 & $2+3$ & 12 & 0,042 & 0,043 & $-0,022$ & 0 \\
\hline UDGH & $1+2$ & 14 & 0,137 & 0,133 & 0,026 & 0 \\
\hline
\end{tabular}

${ }^{1}$ Total number of SNPs that deviate from HWE after multiple test correction.

\section{Results}

\section{PCR design}

We identified 3 candidate genes as not being suitable for a specific PCR-based screen. The candidate genes Alpha-expansin, UDGP, and $U D G H$ are found in two almost identical copies in the $P$. trichocarpa genome (Alpha-expansin: $92,5 \%$ identity of coding sequence, LG 1 and 9; UDGP: $93,7 \%$ identity of coding sequence, LG 4 and 17, UDGH: 92,9\% identity of coding sequence, LG 4 and 17). Alpha-expansin and UDGP do not allow any copy-specific primer design and therefore failed our PCR criteria. However, for UDGH we managed to specifically target the gene copy that is located on LG 4. Another candidate gene PIP2.5 belongs to the gene family of aquaporins of which several paralogs are found in the $P$. trichocarpa genome. Since it was not possible to resolve the gene orthology for PIP2.5, this gene was not used further in this study. The stable protein $S p 1$ is found in two copies both located in close proximity on LG 10 . Since the $S p 1$ locus is duplicated only partially, $P$. trichocarpa- and $P$. tremula-specific primers for both gene products were designed.

\section{P. tremula-specific PCR optimization}

We designed 18 P. trichocarpa-derived primer pairs covering 11 candidate genes and tested them on genomic DNA derived from a batch of $10 P$. tremula trees and one $P$. trichocarpa tree. 16 primer pairs resulted in successful amplification of tremula-specific PCR fragments that were eventually sequenced and analyzed. Two primer sets ( $p t k 2$, exon 7 and 8, sp1, short fragment) failed in $P$. tremula indicating significant sequence differences between both species. Sequence information derived from each species was compared and in case of differences in the sequence, primers specific for $P$. tremula were designed. These $P$. tremula specific primers flanked the coding region (exons) of our candidate gene and expanded circa 50 to $200 \mathrm{bp}$ into the adjacent sequence of the intron. We established PCR and sequencing conditions for 16 P. tremula-specific PCR primer pairs and 6 additional sequencing primers (Table 2). Among these 38 primers, 10 showed sequence differences between both species exhibiting 1 to 3 nucleotide mismatches or even a deletion of 6 nucleotides. Most of these primers (9 of 10) were located in non-coding sequence (introns, 
UTRs, and non-genic regions) of the gene locus and flanked the informative exons.

\section{Species-specific PCR design is required to reduce any allele bias}

Due to our screening focus on informative coding sequence, $63 \%$ of our P. tremula-specific primer binding sites are located in non-coding regions such as introns and UTRs that are expected to be less conserved than the coding sequence. Indeed 9 of 24 non-coding primer binding sites actually showed differences in the nucleotide sequence when comparing $P$. tremula and $P$. trichocarpa, whereas only 1 of 14 primer binding sites differed in coding sequence (Table 2 ). To test if even minor nucleotide variation in the primer binding sites could result in an allele-specific amplification bias, we detected SNPs for four amplicons making use of either $P$. tremula or $P$. trichocarpa derived primer pairs. These primer binding sites differed either in one, two, or three nucleotides ( $d r s 1$, exon 3; $d r s 1$, exon 4; erecta, exon 23 and 24) or they span a species-specific indel in the 3' region of the reverse primer $(\mathrm{mt2a})$. P. trichocarpa- or $P$. tremula-specific primer pairs were applied to the $P$. tremula collection. All four primer sets amplified fragments with PCR failure rates between 1.1 and $5.7 \%$ irrespective of which primer pairs were used (Table 4).

To determine any potential allele-specific bias in the identification of SNPs, we screened all trees individually for SNPs and did an initial statistical analysis to judge the quality of data in our collection (Table 5). We identified different numbers of SNPs for a given amplicon when using either tremula- or trichocarpa-specific primers. Considering that the SNPs amplified in three independent experiments by the tremula-specific primers are "real" SNPs in the $P$. tremula collection, the trichocarpa-specific primers identified a total of nine additional SNPs and missed twelve SNPs compared to the tremula-specific data sets. We assume that sequence differences in the primer binding sites between trichocarpa and tremula lead to the biased amplification of one of two tremula-alleles. This allele-specific PCR bias results in the relatively large number of SNPs missed by the trichocarpa-specific primers. Alternatively, additional and unspecific primer binding sites could result in the observed miscalling of SNPs.

Analyzing these SNPs and their distribution among the collection in more detail, we observed that a total of 47 P. trichocarpa-amplified SNPs deviate from the Hardy-WeinbergEquilibrium (HWE) compared to 7 SNPs amplified with the $P$. tremula specific primers. The inbreeding coefficient per amplicon over the collection showed a significantly higher proportion of homozygous alleles for the $P$. trichocarpa- compared to $P$. tremula-amplified SNPs. As the trees were collected from different habitats around Germany (Figure 1), we would not expect significant levels of inbreeding and loss of heterozygosity for this collection. These effects are actually observed when applying the P. trichocarpa-specific PCR and sequencing conditions. The P. tremula-specific SNP detection

Table 4. - SNPs identified by trichocarpa- and tremula-specific PCR conditions, comparison of PCR failure, false-positive and false-negative SNPs, inbreeding coefficient, and Hardy-Weinberg equilibrium.

\begin{tabular}{|l|l|c|c|c|c|c|c|}
\hline Gene, exon & PCR specific for & $\begin{array}{c}\text { Failed } \\
\text { PCRs }\end{array}$ & $\begin{array}{c}\text { No. of } \\
\text { SNPS }\end{array}$ & $\begin{array}{c}\text { Additional } \\
\text { SNPs }^{1}\end{array}$ & $\begin{array}{c}\text { Missed } \\
\text { SNPs }^{2}\end{array}$ & F IS $^{3}$ & $\begin{array}{c}\text { Out of } \\
\mathrm{HWE}^{4}\end{array}$ \\
\hline Drs1, exon 3 & P. trichocarpa & 5 & 16 & 4 & 2 & 0,523 & 11 \\
\hline & P. tremula & 1 & 14 & & & 0,095 & 0 \\
\hline Drs1, exon 4 & P. trichocarpa & 4 & 21 & 4 & 2 & 0,675 & 13 \\
\hline & P. tremula & 3 & 19 & & & 0,438 & 3 \\
\hline Erecta, exon 23+24 & P. trichocarpa & 1 & 24 & 0 & 5 & 0,549 & 16 \\
\hline & P. tremula & 5 & 29 & & & 0,243 & 4 \\
\hline Mt2a, exon 2 & P. trichocarpa & 2 & 17 & 1 & 3 & 0,360 & 7 \\
\hline & P. tremula & 2 & 19 & & & 0,030 & 0 \\
\hline
\end{tabular}

${ }^{1}$ SNPs identified by trichocarpa-specific but not by tremula-specific primers.

${ }^{2}$ SNPs missed by trichocarpa-specific primers but identified by tremula-specific primers.

${ }^{3}$ Inbreeding coefficient $\left(\mathrm{F}_{\mathrm{IS}}\right)$ per amplicon, $\mathrm{F}_{\mathrm{IS}}>0$ indiciates an excess of homozygous individuals in the analyzed population $(\mathrm{N}=88)$.

${ }^{4}$ Total number of SNPs that deviate from HWE after multiple test correction (Bonferronie correction $\alpha=0,05 / 81$ ). 
Table 5. - Sequence variation in the P. tremula natural population.

\begin{tabular}{|c|c|c|c|c|c|c|c|c|c|c|c|c|c|}
\hline \multirow[b]{2}{*}{ Gene } & \multirow[b]{2}{*}{ exon } & \multirow{2}{*}{$\begin{array}{l}\text { fragment } \\
\text { length } \\
\text { (bp) }\end{array}$} & \multirow{2}{*}{$\begin{array}{l}\text { Variations } \\
\text { total }\end{array}$} & \multirow{2}{*}{$\begin{array}{l}\text { Indels } \\
\text { total }\end{array}$} & \multirow{2}{*}{$\begin{array}{l}\text { SNPs } \\
\text { total }\end{array}$} & \multicolumn{4}{|c|}{ Coding sequence } & \multicolumn{4}{|c|}{ Non-coding sequence } \\
\hline & & & & & & $\begin{array}{l}\text { Length } \\
(\mathrm{bp})^{1}\end{array}$ & $\begin{array}{c}\text { SNPs } \\
\text { non- } \\
\text { synonymous }\end{array}$ & $\begin{array}{c}\text { SNPS } \\
\text { synonymous }\end{array}$ & $\begin{array}{l}\text { Frequency } \\
\text { cds }\end{array}$ & $\begin{array}{l}\text { Length } \\
(\mathrm{bp})^{1}\end{array}$ & $\begin{array}{c}\text { SNPs } \\
\text { (UTR, } \\
\text { nongenic) }\end{array}$ & $\begin{array}{l}\text { SNPS } \\
\text { (intron) }\end{array}$ & $\begin{array}{l}\text { Frequency } \\
\text { non-cds }\end{array}$ \\
\hline Drs1 & $\begin{array}{l}3 \\
4 \\
\end{array}$ & $\begin{array}{l}631 \\
555 \\
\end{array}$ & $\begin{array}{l}15 \\
22 \\
\end{array}$ & $\begin{array}{l}1 \\
3 \\
\end{array}$ & $\begin{array}{l}14 \\
19 \\
\end{array}$ & $\begin{array}{c}408 \\
99\end{array}$ & $\begin{array}{l}3 \\
1 \\
\end{array}$ & $\begin{array}{l}4 \\
1 \\
\end{array}$ & $\begin{array}{l}58 \\
50\end{array}$ & $\begin{array}{l}223 \\
456 \\
\end{array}$ & $\begin{array}{l}0 \\
0\end{array}$ & $\begin{array}{c}7 \\
17 \\
\end{array}$ & $\begin{array}{l}32 \\
27 \\
\end{array}$ \\
\hline Erecta & $\begin{array}{l}23+24 \\
25+26 \\
\end{array}$ & $\begin{array}{c}997 \\
1175 \\
\end{array}$ & $\begin{array}{l}30 \\
20 \\
\end{array}$ & $\begin{array}{l}1 \\
1 \\
\end{array}$ & $\begin{array}{l}29 \\
19 \\
\end{array}$ & $\begin{array}{c}498 \\
616^{1} \\
\end{array}$ & $\begin{array}{l}1^{3} \\
7 \\
\end{array}$ & $\begin{array}{c}3 \\
11 \\
\end{array}$ & $\begin{array}{c}125 \\
36 \\
\end{array}$ & $\begin{array}{l}499 \\
44^{1} \\
\end{array}$ & $\begin{array}{l}0 \\
0\end{array}$ & $\begin{array}{c}25 \\
1 \\
\end{array}$ & $\begin{array}{l}20 \\
22 \\
\end{array}$ \\
\hline Kpt1 & $7-10$ & 698 & 18 & 1 & 17 & 397 & 6 & 3 & 40 & 301 & 0 & 8 & 38 \\
\hline Kup1 & $\begin{array}{c}2+3 \\
9\end{array}$ & $\begin{array}{l}577 \\
731\end{array}$ & $\begin{array}{l}4 \\
5 \\
\end{array}$ & $\begin{array}{l}0 \\
0\end{array}$ & $\begin{array}{l}4 \\
5 \\
\end{array}$ & $\begin{array}{l}394 \\
676 \\
\end{array}$ & $\begin{array}{l}1 \\
2 \\
\end{array}$ & $\begin{array}{l}1 \\
3 \\
\end{array}$ & $\begin{array}{l}197 \\
135\end{array}$ & $\begin{array}{c}183 \\
55\end{array}$ & $\begin{array}{l}0 \\
0\end{array}$ & $\begin{array}{l}2 \\
0\end{array}$ & $\begin{array}{c}92 \\
0\end{array}$ \\
\hline$M t 2 a$ & $1+2$ & 665 & 22 & 1 & 21 & 237 & 4 & 2 & 40 & 428 & 11 & 4 & 29 \\
\hline Ptk2 & $9+10$ & 427 & 18 & 2 & 16 & 333 & 5 & 7 & 28 & 94 & 0 & 4 & 24 \\
\hline Ptm5 & $\begin{array}{c}1 \\
3+4\end{array}$ & $\begin{array}{l}630 \\
757\end{array}$ & $\begin{array}{l}20 \\
18\end{array}$ & $\begin{array}{l}2 \\
1\end{array}$ & $\begin{array}{l}18 \\
17\end{array}$ & $\begin{array}{l}182 \\
204\end{array}$ & $\begin{array}{l}0 \\
2\end{array}$ & $\begin{array}{l}4 \\
2\end{array}$ & $\begin{array}{l}46 \\
51\end{array}$ & $\begin{array}{l}448 \\
553\end{array}$ & $\begin{array}{c}10 \\
0\end{array}$ & $\begin{array}{c}4 \\
13 \\
\end{array}$ & $\begin{array}{l}32 \\
43\end{array}$ \\
\hline Ptork & $\begin{array}{l}3+4 \\
8+9\end{array}$ & $\begin{array}{l}407 \\
576 \\
\end{array}$ & $\begin{array}{l}13 \\
10 \\
\end{array}$ & $\begin{array}{l}1 \\
0\end{array}$ & $\begin{array}{l}12 \\
10 \\
\end{array}$ & $\begin{array}{l}343 \\
337\end{array}$ & $\begin{array}{l}1 \\
4\end{array}$ & $\begin{array}{l}4 \\
3 \\
\end{array}$ & $\begin{array}{l}80 \\
48\end{array}$ & $\begin{array}{c}64 \\
239 \\
\end{array}$ & $\begin{array}{l}0 \\
0\end{array}$ & $\begin{array}{l}3 \\
7 \\
\end{array}$ & $\begin{array}{l}31 \\
80 \\
\end{array}$ \\
\hline SLAC & $2+3$ & 484 & 13 & 1 & 12 & 234 & 0 & 2 & 117 & 250 & 0 & 10 & 25 \\
\hline Sp1 & $1+2$ & 869 & 14 & 0 & 14 & 347 & 1 & 2 & 116 & 522 & 9 & 2 & 47 \\
\hline UDGH & 1 & 802 & 16 & 0 & 16 & 761 & 2 & 12 & 54 & 41 & 2 & 0 & 21 \\
\hline Total & 29 & 11,190 & 258 & 15 & 243 & 6,122 & 40 & 64 & & 4,553 & 32 & 107 & \\
\hline
\end{tabular}

${ }^{1}$ Length of screened coding/non-coding sequence: this number represents the actually resolved and finally screened bp, in case of erecta (exon $25+26$ ) the amplified PCR fragment was sequenced only partially although three different sequencing primers have been used. This is based on the large part of intronic sequence that shows a high content of repetitive regions.

${ }^{2}$ Untranslated regions, 5' UTR: mta2a, $160 \mathrm{bp}$; ptm5 exon1, $225 \mathrm{bp}$; sp1, $75 \mathrm{bp}$; and UDGH, 41 bp upstream of proposed translation initiation site considered. 3'UTR: $s p 1,200$ bp downstream of stop codon considered.

${ }^{3}$ SNP erecta_1_604 disrupts the 3' donor position of the exon 24 splice site, which might influence the full-length translation of the erecta peptide.

Non-synonymous substitutions lead to changes in the amino acid composition or affects predicted splice sites, synonymous substitutions do not affect the amino acid composition, SNPs located in introns are considered as silent mutations.

resulted in a much milder loss of heterozygosity (0.030 to 0.438$)$ and less individuals that deviate from HWE (Table 4) for the same batch.

\section{Sequence variation within the P. tremula collection}

In an initial set of fourteen candidate genes, we focused on genes with a potential physiological function during stress-mediated responses in the context of drought tolerance and xylogenesis (Table 1). We successfully established $P$. tremula-specific amplification and resequencing conditions for 29 exons representing 11 candidate genes (circa 1/3 of all predicted exons).

The established 16 amplicons cover $6.1 \mathrm{~kb}$ of coding sequence and additional $4.6 \mathrm{~kb}$ of noncoding sequence (Table 5). Processing all amplicons on this collection, we generated about $3 \mathrm{Mb}$ of sequence information. We identified 258 genetic variants, 15 of these represent indels that are located exclusively in non-coding regions and 243 are SNPs that are found in coding and non-coding regions of candidate genes.
The overall frequency of SNPs is 1 SNP in 44 $\mathrm{bp}$, which is higher compared to recent studies reporting 1 in $70 \mathrm{bp}$ and 1 in $54 \mathrm{bp}$, respectively (INGVARSSON, 2005; ISMAIL et al., 2012). On average, we identified twice the number of SNPs in non-coding regions (140 SNPs with an average frequency of 1 SNP in $35 \mathrm{bp}$ ) than in coding regions (103 SNPs with an average frequency of $1 \mathrm{SNP}$ in $76 \mathrm{bp}$ ) supporting the higher degree of sequence conservation in coding compared to non-coding regions. However, the frequency of SNPs varied between amplicons ranging from $1 \mathrm{SNP}$ in $20 \mathrm{bp}$ in the non-coding region of erecta (exon 23 and 24) to 1 in $197 \mathrm{bp}$ in the coding region of Kup1 (exon 2 and 3). Six of 243 SNPs were found in more than two allelic variants in our collection whereas all other SNPs are bi-allelic.

To get some insights into the potential physiological effect of a SNP located in the coding sequence, we translated the allelic variants based on the predicted annotation of our candidate genes. We identified one SNP in the erecta gene that affects the 3' donor site of the pre- 
dicted splice site of exon 24, which might cause an early termination of the gene product. In addition, we found $40 \mathrm{SNPs}$ that lead to changes in the translated amino acids, which are classified as non-synonymous substitutions. $64 \mathrm{SNPs}$ in coding areas do not cause changes in the amino acid composition (synonymous substitution), along with 32 SNPs located in UTRs and adjacent non-genic regions and 107 SNPs located in introns.

\section{Diversity of analyzed genes in the Populus tremula collection}

Since the $P$. tremula collection is a newly established resource for potential breeding approaches, we wanted to explore its heterogeneity to consider the suitability for ecological and evolutionary studies. As parameters for the genetic heterogeneity of a given population, the expected and observed heterozygosities, and the deviation from HWE were calculated for each detected SNP marker (Table 3). Only $4.5 \%$ of all detected SNPs deviate from HWE $(\alpha=0,0002$ after Bonferroni correction). These eleven deviating SNPs are concentrated mainly in three different amplicons with 4 deviating SNPs in $d r s 1$, exon4 (21\%); 3 in ptk2, exon 9 and 10 (19\%); and 3 in ptork, exon 3 and 4 (25\%); in addition, 1 deviating SNP is detected in erecta, exon 23 and $24(3.4 \%)$.

\section{Discussion}

SNPs are considered as the basic detectable unit of genetic variations, which are used as DNA-based markers. Hence, informative SNPs represent an attractive resource for genotyping and breeding strategies due to their wide distribution throughout the genome and the fact that they are easy to score and amenable to largescale applications (GARVIN et al., 2010; SEEB et $a l$., 2011). Our approach was focused on the detection of SNPs in informative regions of eleven candidate genes that consist of coding $(57 \%)$ as well as exon-spanning non-coding areas $(43 \%)$. As stated by SLATE et al. (2009) and GARVIN et al. (2010), the critical point of this method is the design of species-specific primers and PCR-optimization to avoid any bias in the further analysis.

Applying the method described in the present study on a total of fourteen candidate genes, we managed to design species-specific primers for sixteen amplicons covering mainly coding regions in eleven genes (Table 1 and 2). Three genes failed in this approach since they are either found as duplicates or exist as two almost identical paralogs in the $P$. trichocarpa genome, which is partially duplicated (TUSKAN et al., 2006; RODGERS-MELNICK et al., 2012). We started by using $P$. trichocarpa derived primers to amplify from $P$. tremula genomic DNA. This restrictive cross-species primer design strategy resulted in $89 \%$ specific amplification products compared to $14 \%$ or 61 to $67 \%$, which have been described for other than chloroplast loci in P. tremula and other poplar species (INGVARSSON, 2008; JosePH and LeXer, 2008; OLSON et al., 2010; SchroEDER et al., 2012). These $P$. tremula derived amplification products provided the species-specific sequence information that is used for the design and optimization of specific $P$. tremula derived primers. The critical step of our pipeline was the design and experimental validation of $P$. tremula specific primers, a procedure that was proposed for SNP detection in non-model species (Slate et al., 2009; GARVIN et al., 2010). The systematic comparison of SNP data derived from individual $P$. tremula trees after amplification with either $P$. tremula or $P$. trichocarpa specific primers revealed a significant allele-bias of discovered SNPs depending on the specificity of primers. Even minor sequence variations (one and two nucleotides) in the primer binding sites could lead to miscalling of heterozygous as well as homozygous SNPs. These errors could consequentially result in a misleading population structure for the $P$. tremula collection. This effect was demonstrated by the massive inbreeding tendency and large number of HWE outliers when using P. trichocarpa derived primer conditions that represent cross-species conditions. This potentially misleading population structure is massively reduced in our collection when using P. tremula-specific primers indicating that a careful design of species-specific PCR conditions is an essential prerequisite for any robust and reliable SNP detection approach no matter which SNP discovery tool is used.

\section{Conclusions}

A prerequisite for reliable SNP discovery in non-model organisms such as $P$. tremula is the careful design of PCR amplicons that are highly specific for the gene of interest in this species. 
We established a method that combines in silico PCR design with experimental confirmation and adjustment of data, which is required to avoid any allele bias in the SNP data. Making use of the present method, we established fourteen new $P$. tremula specific genic regions.

Applying this approach to a newly established collection of $P$. tremula trees led to the identification of 243 SNPs in this population. A total of $95 \%$ of SNPs does not deviate from HWE, which is consistent with the finding that the majority of analyzed regions do not show a significant in- or out-breeding behavior. This initial analysis indicates that a robust speciesspecific pipeline is required for the reliable detection of SNPs that then can be used for the detailed analysis of population structure and potential adaptive behavior of SNP markers.

\section{Acknowledgements}

We thank IAN HENRY and NAHARAJAN LAKSHMANAPERUMAL (MPI CBG Bioinformatics Service) for their Bioinformatic support, KATJA Steinberg-Baines, Sylvia SchimpKe and Katrin WINKLER for excellent technical support, FRANK HoRTIG for assistance during tree sampling, VineEth SuREndRanath (MPI CBG) and ANTJE JAROSCH for scientific discussions and critical reading of the manuscript, Staatsbetrieb Sachsenforst for given us access to plant material. We thank two unknown referees for helpful comments. The project "ISOWOOD BREEDING" was financially supported by the Bundesministerium fuer Bildung und Forschung, Schwerpunktprogramm "Bioenergy 2021", 0315427A.

\section{References}

Arend, M., A. Stinzing, C. Wind, K. Langer, A. LAtz, P. Ache, J. Fromm and R. HedRICH (2005): Polarlocalised poplar $\mathrm{K}^{+}$channel capable of controlling electrical properties of wood-forming cells. Planta 223: $140-148$.

Bhangale, T. R., M. Stephens and D. A. Nickerson (2006): Automating resequencing-based detection of insertion-deletion polymorphisms. Nature Genetics 38: 1457-1462.

CARDon, L. R. and J. I. Bell (2001): Association study designs for complex diseases. Nature reviews. Genetics 2: 91-99.

Cseke, L. J., J. Zheng and G. K. Podila (2003): Characterization of PTM5 in aspen trees: a MADS- box gene expressed during woody vascular development. Gene 318: 55-67.

Doyle, J. J. and J. L. DoYle (1987): A rapid DNA isolation procedure for small quantities of fresh leaf tissue. Phytochemical Bulletin 19: 11-15.

ECKENWALDER, J. E. (1996): Systematics and evolution of Populus, pp. 7-32. In: Biology of Populus and Its Implications for Management and Conservation, edited by R. F. STETTLER, N.R.C. Research Press, Ottawa, Canada.

Garvin, M. R., K. SAItoh and A. J. Gharrett (2010): Application of single nucleotide polymorphisms to non-model species: a technical review. Molecular Ecology Resources 10: 915-934.

Goodstein, D. M., S. Shu, R. Howson, R. Neupane, R. D. Hayes, J. Fazo, T. Mitros, W. Dirks, U. HellSTEN and N. Putnam (2012): Phytozome: a comparative platform for green plant genomics. Nucleic Acids Research: 1178-1186.

Gray-Mitsumune, M., E. J. Mellerowicz, H. Abe, J. Schrader, A. Winzell, F. Sterky, K. Blomqvist, S. McQueen-Mason, T. T. Teeri and B. SundberG (2004): Expansins abundant in secondary xylem belong to subgroup A of the alpha-expansin gene family. Plant Physiology 135: 1552-1564.

Hamanishi, E. T., B. R. Thomas and M. M. CAMpBell (2012): Drought induces alterations in the stomatal development program in Populus. Journal of Experimental Botany 63: 4959-4971.

Helyar, S. J., J. Hemmer-Hansen, D. BeKkevold, M. I. TAYlor, R. Ogden, M. T. Limborg, A. Cariani, G. E. Maes, E. Diopere and G.. R. Carvalho (2011): Application of SNPs for population genetics of nonmodel organisms: new opportunities and challenges. Molecular Ecology Resources 11: $123-136$.

IngVARSsON, P. K. (2005): Nucleotide polymorphism and linkage disequilibrium within and among natural populations of European aspen (Populus tremula L., Salicaceae), Genetics 169: 945-953.

IngVARSSON, P. K. (2008): Multilocus patterns of nucleotide polymorphism and the demographic history of Populus tremula. Genetics 180: 329-340.

ISMaIl, M., R. Y. SOOLANAYAKANAHALly, P. K. InGVARSson, R. D. Guy, S. Jansson, S. N. Silim and Y. A. EL-KASSABY (2012): Comparative nucleotide diversity across North American and European populus species. Journal of Molecular Evolution 74: $257-272$.

Johansson, H., F. Sterky, B. Amini, J. LundeberG and L. A. KLECZKOWSKI (2002): Molecular cloning and characterization of a cDNA encoding poplar UDP-glucose dehydrogenase, a key gene of hemicellulose/pectin formation. Biochimica et Biophysica Acta 1576: 53-58.

Joseph, J. A. and C. Lexer (2008): A set of novel DNA polymorphisms within candidate genes potentially involved in ecological divergence between Populus alba and P. tremula, two hybridizing European forest trees. Molecular Ecology Resources 8: 188-192. 
Kelleher, S. R., N. Levsen, M. S. Olson and P. TifFIN (2012): Local Adaptation in the Flowering-Time Gene Network of Balsam Poplar, Populus balsamifera L. Molecular Biology and Evolution 29: 3143-3152.

Langer, K., P. Ache, D. Geiger, A. Stinzing, M. Arend, C. Wind, S. Regan, J. Fromm and R. HEDRICH (2002): Poplar potassium transporters capable of controlling $\mathrm{K}^{+}$homeostasis and $\mathrm{K}^{+}$dependent xylogenesis. The Plant journal: for cell and molecular biology 32: 997-1009.

Lee, J. H., W. Terzaghi, G. Gusmaroli, J. B. CharRon, H. J. Yoon, H. Chen, Y. J. He, Y. Xiong and X. W. Deng (2008): Characterization of Arabidopsis and rice DWD proteins and their roles as substrate receptors for CUL4-RING E3 ubiquitin ligases. The Plant Cell 20: 152-167.

Li, X., C. Zhu, C. T. Yeh, W. Wu, E. M. Takacs, K. A. Petsch, F. Tian, G. Bai, E. S. Buckler, G. J. Muehlbauer et al. (2012): Genic and nongenic contributions to natural variation of quantitative traits in maize. Genome Research DOI 10.1101/gr.140277.112

LiU, K. and S. V. Muse (2005): PowerMarker: an integrated analysis environment for genetic marker analysis. Bioinformatics 21: 2128-2129.

Marjanovic, Z., N. Uehlein, R. Kaldenhoff, J. J. ZwiAZEK, M. Weiss, R. HAMPP and U. NEHLs (2005): Aquaporins in poplar: what a difference a symbiont makes!. Planta 222: 258-268.

Masle, J., S. R. Gilmore and G. D. Farquhar (2005): The ERECTA gene regulates plant transpiration efficiency in Arabidopsis. Nature 436: 866-870.

Nickerson, D. A., V. O. Tobe and S. L. TAYlor (1997): PolyPhred: automating the detection and genotyping of single nucleotide substitutions using fluorescence-based resequencing. Nucleic Acids Research 25: 2745-2751.

Olson, M. S., A. L. Robertson, N. TAKebayashi, S. Silim, W. R. Schroeder and P. Tiffin (2010): Nucleotide diversity and linkage disequilibrium in balsam poplar (Populus balsamifera). The New Phytologist 186: 526-536.

Rozen, S. and H. Skaletsky (2000): Primer3 on the WWW for general users and for biologist programmers. Methods in Molecular Biology 132: 365-386.

Schroeder, H., A. M. Hoeltken and M. Fladung (2012): Differentiation of Populus species using chloroplast single nucleotide polymorphism (SNP) markers - essential for comprehensible and reliable poplar breeding. Plant Biology 14: 374-381.
Seeb, L. W., W. D. Templin, S. SAto, S. Abe, K. WARheit, J. Y. PARK and J. E. Seeb (2011): Single nucleotide polymorphisms across a species' range: implications for conservation studies of Pacific salmon. Molecular Ecology Resources 11 Suppl 1: 195-217.

SEIfERT, S., B. Vornam and R. Finkeldey (2012): DNA sequence variation and development of SNP markers in beech (Fagus sylvatica L.). European Journal of Forest Research 131: 1761-1770.

Slate, J., J. Gratten, D. Beraldi, J. Stapley, M. Hale and J. M. Pemberton (2009): Gene mapping in the wild with SNPs: guidelines and future directions. Genetica 136: 97-107.

Strauss, S. H. and F. M. Martin (2004): Poplar genomics comes of age. New Phytologist 164: 1-4.

Street, N. R., O. Skogstrom, A. Sjodin, J. Tucker, M. Rodriguez-Acosta, P. Nilsson, S. JANsson and G. TAYLOR (2006): The genetics and genomics of the drought response in Populus. Plant Journal 48: 321-341.

Tuskan, G. A., S. Difazio, S. Jansson, J. Bohlmann, I. Grigoriev, U. Hellsten, N. Putnam, S. Ralph, S. Rombauts, A. SAlamov et al. (2006): The genome of black cottonwood, Populus trichocarpa (Torr. \& Gray). Science 313: 1596-1604.

Vahisalu, T., H. Kollist, Y. F. Wang, N. Nishimura, W. Y. Chan, G. Valerio, A. Lamminmaki, M. Brosche, H. Moldau and R. Desikan et al. (2008): SLAC1 is required for plant guard cell S-type anion channel function in stomatal signalling. Nature 452: 487-491.

Wang, W. X., D. Pelah, T. Alergand, O. Shoseyov and A. Altman (2002): Characterization of SP1, a stress-responsive, boiling-soluble, homo-oligomeric protein from aspen. Plant Physiology 130: 865-875.

Wilkins, O., L. Waldron, H. Nahal, N. J. Provart and M. M. CAMPBell (2009): Genotype and time of day shape the Populus drought response. The Plant Journal 60: 703-715.

Winkler, S., N. Gscheidel and M. BRAND (2011): Mutant generation in vertebrate model organisms by TILLING. Methods in Molecular Biology 770: 475-504.

Yoshiura, K., A. Kinoshita, T. Ishida, A. Ninokata, T. Ishikawa, T. Kaname, M. Bannai, K. Tokunaga, S. SONODA and R. KomAKI et al. (2006): A SNP in the ABCC11 gene is the determinant of human earwax type. Nature Genetics 38: 324-330. 